\title{
ANTISIPASI KETAHANAN EKONOMI KELUARGA DI KABUPATEN LABUHANBATU SELATAN
}

\author{
Ade Parlaungan Nasution dan Pristiyono \\ Sekolah Tinggi Ilmu Ekonomi (STIE) Labuhanbatu
}

\begin{abstract}
Abstrak
Stabilitas ekonomi yang tidak merata menyebabkan sebagian dari penduduk yang keterbatasan ekonomi menjadi semakin miskin karena tingginya kebutuhan hidup yang harus dipenuhi. Usaha Mikro Kecil dan Menengah (UMKM) adalah basis ekonomi bangsa yang dapat menjadi alternative pilihan guna mengangkat perekonomian negara dari keterpurukan. Penelitian ini hanya menggunakan empat variabel, yaitu variabel bebas pendidikan $\left(X_{1}\right)$, pelatihan $\left(X_{2}\right)$, modal $\left(X_{3}\right)$ dan teknologi $\left(X_{4}\right)$, dan variabel terikat ketahanan ekonomi masyarakat $(Y)$. Populasi yang digunakan dalam penelitian adalah para entrepreneur (pemilik atau manajer) UKM yang tersebar di Kabupaten Labuhanbatu Selatan yang berjumlah 50 responden. Sampel yang dipilih menggunakan purposive sampling untuk memperoleh data primer dalam penelitian ini yaitu kuesioner dan analisis regresi berganda. Berdasarkan hasil penelitian dapat ditarik beberapa kesimpulan untuk menjawab rumusan masalah yakni pendidikan tidak berpengaruh terhadap ketahanan ekonomi masyarakat. Pelatihan berpengaruh terhadap ketahanan ekonomi masyarakat. Modal tidak serta merta berpengaruh terhadap ketahanan ekonomi masyarakat. Terakhir, teknologi menjadi variabel paling dominan berpengaruh terhadap ketahanan ekonomi masyarakat.
\end{abstract}

\section{Kata Kunci : Pendidikan, Pelatihan, Modal, Teknologi, Ketahanan Ekonomi.}

\section{PENDAHULUAN}

\section{Latar Belakang Masalah}

Pembangunan di daerah merupakan bagian yang tidak dapat dipisahkan dari konsep dan tujuan pembangunan nasional, program-program pembangunan yang berlangsung selama ini diyakini telah mampu menggerakkan dinamika bangsa Indonesia menuju kearah taraf kemajuan seperti yang kita rasakan selama ini. Sebagai konsekuensi dari pembangunan nasional yang sedang berlangsung, berbagai daerah telah diberi kesempatan oleh pemerintah pusat untuk membenahi diri dalam menentukan sikapnya sendiri yang diwujudkan dalam bentuk pemekaran wilayah dengan berbagai alasan kepentingan yang menyertainya, seperti: latar belakang sejarah, peningkatan pelayanan pada masyarakat, pemerataan pembangunan dan perimbangan keuangan antara pusat - daerah yang diformat dalam suatu wadah politik dengan kemasan yang berlabelkan "Pemerintahan Otonomi Daerah".

Kabupaten Labuhanbatu Selatan merupakan salah satu daerah otonom baru yang merupakan hasil pemekaran dari Kabupaten Labuhanbatu yang diresmikan pada tanggal 21 Juli 2008 sesuai dengan Undang-undang No. 22 Tahun 2008 tentang pembentukan Kabupaten Labuhanbatu Selatan di Provinsi Sumatera Utara. Labuhanbatu Selatan merupakan salah satu Kabupaten dari pemekaran Kabupaten Labuhanbatu yang dibagi menjadi kabupaten yaitu Kabupaten Labuhanbatu, Kabupaten Labuhanbatu Selatan dan Kabupaten Labuhanbatu Utara. Total luas wilayah Kabupaten Labuhanbatu Selatan sekitar $4.35 \%$ dari luas wilayah Provinsi 
Sumatera Utara. Luas wilayah Kabupaten Labuhanbatu Selatan adalah 311.600 Ha yang terdiri dari 5 Kecamatan, 52 Desa, dan 2 Kelurahan defenitif. Adapun lima kecamatan yang ada di Kabupaten Labuhanbatu Selatan ialah sebagai berikut Kecamatan Sungai Kanan, Kecamatan Kampung Rakyat, Kecamatan Torgamba, Kecamatan Sei Kanan dan Kecamatan Silangkitang.

Ekonomi dikatakan mengalami pertumbuhan apabila produksi barang dan jasa meningkat dari tahun sebelumnya, pembangunan ekonomi suatu daerah identik dengan jumlah penduduk disertai dengan berbagai perubahan yang meningkatkan sumber-sumber produktif. Namun, dampak dari pertumbuhan penduduk di suatu daerah akan mengalami kesulitan dalam penyerapan tenaga kerja, membatasi investasi dan menghambatkan produktivitas.

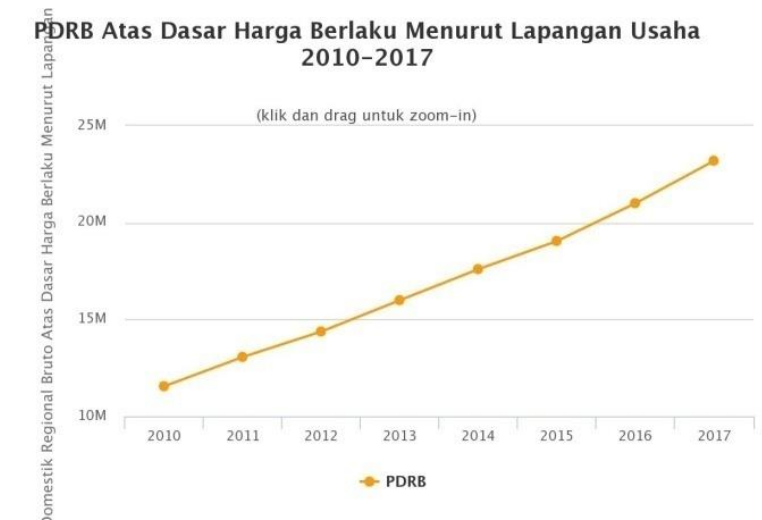

Sumber : BPS Kab. Labuhanbatu Selatan, 2019.

Sampai saat ini pertumbuhan ekonomi di tiap daerah yang ada di Indonesia semakin meningkat dengan beberapa upaya dari pemerintah. Bahkan daerah-daerah yang mengalami pemekaran kini lebih fokus mengejar ketertinggalan dengan meningkatkan perekonomian melalui Sumber Daya Manusia (SDM), sumber daya alam (SDA), perbaikan pendidikan bagi masyarakat yang tertinggal serta beberapa faktor-faktor yang mendukung perkembangan. Pada tahun 2017, pengeluaran rata-rata perkapita sebulan di Kabupaten Labuhanbatu Selatan sebesar 883.232 rupiah, yang terdiri dari 543.064 rupiah untuk pengeluaran makanan $(61,49 \%)$ dan 340.168 rupiah untuk pengeluaran bukan makanan $(38,51 \%)$. Penduduk dengan pengeluaran antara500.000 rupiah hingga 749.999 rupiah sebulan merupakan yang terbanyak $(36,04 \%)$, diikuti penduduk dengan pengeluaran 750.000 hingga 999.999 rupiah $(31,51 \%)$ dan penduduk dengan pengeluaran $1.000 .000-1.249 .999$ rupiah $(14,57 \%)$.

Stabilitas ekonomi yang tidak merata menyebabkan sebagian dari penduduk yang keterbatasan ekonomi menjadi semakin miskin karena tingginya kebutuhan hidup yang harus dipenuhi. Usaha Mikro Kecil dan Menengah (UMKM) adalah basis ekonomi bangsa yang dapat menjadi alternative pilihan guna mengangkat perekonomian negara dari keterpurukan. Perhatian pada pengembangan sektor Usaha Mikro Kecil dan Menengah (UMKM) memberikan makna tersendiri pada usaha menekan angka kemiskinan suatu negara. Pertumbuhan dan pengembangan sektor UMKM sering diartikan sebagai salah satu indicator keberhasilan pembangunan, khususnya bagi negara-negara yang memiliki income perkapita yang rendah (Primiana, 2009). Demikian halnya dengan ketahanan ekonomi suatu daerah juga ditopang dari banyak Usaha Mikro Kecil dan Menengah yang mulai mengembangkan strategi bisnis agar mampu 


\section{TINJAUAN PUSTAKA}

Pada Bab I pasal 1 UU No 20 Tahun 2008 tentang Usaha Mikro, Kecil, dan Menengah(UMKM), maka yang dimaksud dengan Usaha Mikro, Kecil, dan Menengah adalah :

1) Usaha Mikro adalah usaha produktif milik orang perorangan dan/atau badan usaha perorangan yang memenuhi kriteria Usaha Mikro sebagaimana diatur dalam Undang-Undang ini.

2) Usaha Kecil adalah usaha ekonomi produktif yang berdiri sendiri, yang dilakukan oleh orang perorangan atau badan usaha yang bukan merupakan anak perusahaan atau bukan cabang perusahaan yang dimiliki, dikuasai, atau menjadi bagian baik langsung maupun tidak langsung dari Usaha Menengah atau Usaha Besar yang memenuhi kriteria Usaha Kecil se-bagaimana dimaksud dalam Undang-Undang ini.

3) Usaha Menengah adalah usaha ekonomi produktif yang berdiri sendiri, yang dilakukan oleh orang perorangan atau badan usaha yang bukan merupakan anak perusahaan atau cabang perusahaan yang dimiliki, dikuasai, atau menjadi bagian baik langsung maupun tidak langsung dengan Usaha Kecil atau Usaha Besar dengan jumlah kekayaan bersih atau hasil penjualan tahunan sebagaimana diatur dalam Undang-Undang ini.

Berdasarkan definisi diatas maka pada intinya Usaha Mikro, Kecil, dan Menengah adalah suatu bentuk usaha ekonomi produktif yang dilakukan oleh orang perseorangan atau badan usaha perorangan yang memenuhi kriteria Usaha Mikro, Kecil, dan Menengah.

\section{METODE}

Jenis penelitian yang digunakan adalah metode kuantitatif, yaitu suatu konsep/ide diukur dengan menggunakan teknik yang menghasilkan angka-angka (Jonker et al, 2011). Angka ini yang dianggap mewakili konsep/ide kemudian dianalisis. Penelitian ini hanya menggunakan empat variabel, yaitu variabel bebas pendidikan $\left(\mathrm{X}_{1}\right)$, pelatihan $\left(\mathrm{X}_{2}\right)$, modal $\left(\mathrm{X}_{3}\right)$ dan teknologi $\left(\mathrm{X}_{4}\right)$, dan variabel terikat ketahanan ekonomi masyarakat (Y). Populasi yang digunakan dalam penelitian adalah para entrepreneur (pemilik atau manajer) UKM yang tersebar di Kabupaten Labuhanbatu Selatan yang berjumlah 50 responden. Sampel yang dipilih menggunakan purposive sampling untuk memperoleh data primer dalam penelitian ini yaitu kuesioner. Analisis regresi untuk mengetahui arah hubungan antara variabel independen dengan variabel dependen apakah masingmasing variabel independen berhubungan positif atau negatif dan untuk memprediksi nilai dari variabel dependen apabila nilai variabel independen mengalami kenaikan atau penurunan. Data yang digunakan biasanya berskala interval atau rasio.

Persamaan regresi berganda sebagai berikut :

Keterangan:

$$
\mathrm{Y}=\mathrm{a}+b_{1} x_{1}+b_{2} x_{2}+b_{3} x_{3}+b_{4} x_{4}+\mathrm{e}
$$

$\mathrm{Y}=$ Ketahanan Ekonomi Keluarga

$x_{1}=$ Pendidikan

$x_{2}=$ Pelatihan

$x_{3}=$ Modal

$x_{4}=$ Teknologi

$\mathrm{a}=$ Konstanta (nilai $\mathrm{Y}$ apabila X1, X2 ....Xn $=0$ ).

$\mathrm{b}=$ Koefisien regresi (nilai peningkatan ataupun penurunan).

\section{HASIL DAN PEMBAHASAN}




\section{Profil Responden}

Data responden dalam penelitian ini sangat dibutuhkan untuk mengetahui latar belakang responden yang dapat dijadikan masukan untuk menjelaskan hasil yang diperoleh dari penelitian. Karakteristik data responden ini terdiri data mengenai pendidikan, pengalaman, usia, upah, tenaga kerja, jenis kelamin dan skala usaha sebagai berikut :

Tabel 1. Deskripsi Responden

\begin{tabular}{|c|c|c|c|}
\hline No. & Uraian & $\begin{array}{l}\text { Frekuensi } \\
\text { (Orang) }\end{array}$ & $\begin{array}{c}\text { Prosentase } \\
(\%)\end{array}$ \\
\hline \multirow[t]{7}{*}{1.} & \multicolumn{3}{|l|}{ Pendidikan } \\
\hline & Tidak sekolah & 9 & 18,0 \\
\hline & SD & 1 & 2,0 \\
\hline & SMP & 8 & 16,0 \\
\hline & SMA & 13 & 26,0 \\
\hline & Diploma/Sarjana & 19 & 38,0 \\
\hline & Total & 50 & 100 \\
\hline \multirow[t]{4}{*}{2.} & \multicolumn{3}{|l|}{ Pengalaman } \\
\hline & $\mathrm{Ya}$ & 39 & 78,0 \\
\hline & Tidak & 11 & 22,0 \\
\hline & Total & 50 & 100 \\
\hline \multirow[t]{6}{*}{3.} & \multicolumn{3}{|l|}{ Usia } \\
\hline & 17-21 tahun & 6 & 12.0 \\
\hline & $22-35$ tahun & 14 & 28,0 \\
\hline & $26-45$ tahun & 20 & 40,0 \\
\hline & 45 ke atas & 10 & 20,0 \\
\hline & Total & 50 & 100 \\
\hline \multirow[t]{5}{*}{4.} & \multicolumn{3}{|l|}{ Upah } \\
\hline & High & 13 & 26,0 \\
\hline & Low & 16 & 32,0 \\
\hline & Middle & 21 & 42,0 \\
\hline & Total & 50 & 100 \\
\hline \multirow[t]{6}{*}{5.} & \multicolumn{3}{|l|}{ Tenaga Kerja } \\
\hline & Satu & 8 & 16,0 \\
\hline & Dua & 8 & 16,0 \\
\hline & Tiga & 15 & 30,0 \\
\hline & Lebih dari Tiga & 19 & 38,0 \\
\hline & Total & 50 & 100 \\
\hline \multirow[t]{4}{*}{6.} & \multicolumn{3}{|l|}{ Jenis Kelamin } \\
\hline & Laki & 35 & 70,0 \\
\hline & Perempuan & 15 & 30,0 \\
\hline & Total & 50 & 100 \\
\hline \multirow[t]{5}{*}{7.} & \multicolumn{3}{|l|}{ Skala usaha } \\
\hline & Besar & 8 & 16,0 \\
\hline & Kecil & 9 & 18,0 \\
\hline & Menengah & 33 & 66,0 \\
\hline & Total & 50 & 100 \\
\hline
\end{tabular}

Sumber : Data Diolah, 2019. 
Berdasarkan Tabel 1 terlihat bahwa karakteristik responden berdasarkan pendidikan komposisinya lebih banyak yakni Diploma/Sarjana (38\%), responden berdasarkan pengalaman komposisinya lebih banyak yakni Ya $(78 \%)$, responden berdasarkan usia komposisinya lebih banyak yakni usia 26-45 tahun (40\%), responden berdasarkan upah komposisinya lebih banyak yakni Middle (42\%), responden berdasarkan tenaga kerja komposisinya lebih banyak yakni Lebih dari tiga (38\%), responden berdasarkan jenis kelamin komposisinya lebih banyak yakni Laki-laki (35\%), dan responden berdasarkan skala usaha komposisinya lebih banyak yakni Menengah $(33 \%)$.

Adapun rangkuman hasil regresi untuk pengujian hipotesis adalah sebagai berikut:

\section{Tabel 2. Hasil Regresi Linier Berganda}

\begin{tabular}{|c|c|c|c|c|c|c|}
\hline & \multirow{2}{*}{ Model } & \multicolumn{2}{|c|}{$\begin{array}{l}\text { Unstandardized } \\
\text { Coefficients }\end{array}$} & \multirow{2}{*}{$\begin{array}{l}\text { Standardized } \\
\text { Coefficients } \\
\text { Beta }\end{array}$} & \multirow{2}{*}{$\mathbf{t}$} & \multirow{2}{*}{ Sig. } \\
\hline & & $\bar{B}$ & $\begin{array}{l}\text { Std. } \\
\text { Error }\end{array}$ & & & \\
\hline \multirow{9}{*}{1} & (Constant) & 3.240 & 1.431 & & 2.263 & 0.028 \\
\hline & Pendidikan & 0.044 & 0.130 & 0.042 & 0.342 & 0.734 \\
\hline & Pelatihan & 0.347 & 0.128 & 0.310 & 2.717 & 0.009 \\
\hline & Modal & -0.099 & 0.121 & -0.112 & -0.812 & 0.421 \\
\hline & Teknologi & 0.455 & 0.076 & 0.692 & 6.001 & 0.000 \\
\hline & $\mathrm{R}$ & 0.740 & & & & \\
\hline & $\mathrm{R}^{2}$ & 0.547 & & & & \\
\hline & $F_{\text {hitung }}$ & 13.596 & & & & \\
\hline & Sig & 0.000 & & & & \\
\hline
\end{tabular}

Sumber : Data Diolah, 2019.

Berdasarkan tabel di atas diperoleh persamaan regresi berganda berikut :

$$
\mathrm{Y}=3,240+0,044 x_{1}+0,347 x_{2}-0,099 x_{3}+0,455 x_{4}
$$

Berdasarkan output SPSS di atas bahwa angka $\mathrm{R}^{2}$ (R Square) sebesar 0,547 atau (54,7\%). Hal ini menunjukkan bahwa persentase sumbangan pendidikan, pelatihan, modal dan teknologi terhadap ketahanan ekonomi keluarga sebesar 54,7\% sedangkan sisanya sebesar 45,3\% dijelaskan oleh variabel lain yang tidak dimasukkan dalam model penelitian. Berdasarkan hasil output SPSS di atas kita dapat melihat bahwa nilai $\mathrm{F}$ hitung > nilai $\mathrm{F}$ tabel $(13,596>2,57)$ dengan tingkat signifikan di bawah 0,05 yaitu 0,005 . Berdasarkan cara pengambilan keputusan uji simultan dalam analisis regresi dapat disimpulkan bahwa variabel pendidikan $\left(\mathrm{X}_{1}\right)$, pelatihan $\left(\mathrm{X}_{2}\right)$, modal $\left(\mathrm{X}_{3}\right)$ dan teknologi $\left(\mathrm{X}_{4}\right)$ jika diuji secara bersama-sama atau serempak berpengaruh signifikan terhadap ketahanan ekonomi masyarakat (Y). Berdasarkan hasil output SPSS di atas kita dapat melihat dimana nilai t hitung variabel pendidikan $\left(\mathrm{X}_{1}\right)$ lebih kecil dari pada nilai t tabel $(0,342<1,678)$ dengan tingkat signifikan diatas 0,05 yaitu 0,342 . Nilai t hitung variabel pelatihan $\left(\mathrm{X}_{2}\right)$ lebih besar dari pada nilai $t$ tabel $(2,717>1,678)$ dengan tingkat signifikan dibawah 0,05 yaitu 0,009 . Nilai $t$ hitung variabel modal $\left(\mathrm{X}_{3}\right)$ lebih kecil dari pada nilai t tabel $(-0,812>1,678)$ dengan tingkat signifikan diatas 0,05 yaitu 0,421 dan nilai t hitung variabel teknologi $\left(\mathrm{X}_{4}\right)$ lebih besar dari pada nilai t tabel $(6,001>1,678)$ dengan tingkat signifikan dibawah 0,05 yaitu 0,000 .

\section{Pembahasan}




\section{Pengaruh Pendidikan Terhadap Ketahanan Ekonomi Masyarakat}

Penelitian ini menunjukkan bahwa pendidikan tidak berpengaruh terhadap ketahanan ekonomi masyarakat. Sesuai dengan penelitian Nainggolan (2016) membuktikan bahwa tinggi atau rendahnya tingkat pendidikan pemilik UMKM tidak berpengaruh terhadap penghasilan yang diperoleh. Implikasinya adalah tidak perlu sekolah yang tinggi bila sekedar mendapatkan penghasilan sebesar UMR. Sesuai dengan penelitian Tarigan (2006) bahwa tingkat pendidikan tidak berdampak nyata kepada pendapatan karena letak lokasi di pedalaman atau pedesaan tidak punya pilihan kegiatan usaha atau jenis pekerjaan. Dari analisis yang dilakukan meskipun profil responden pada penelitian ini paling dominan berpendidikan diploma/sarjana sebesar 38 persen, hal ini berarti responden yang ditemui merupakan pemilik usaha yang memiliki penghasilan lebih dari hasil usaha yang dimilikinya, kemudian pemilik usaha memiliki keinginan melanjutkan pendidikan ke perguruan tinggi dengan berbagai pilihan jurusan sehingga ilmu dan pengetahuan yang diperoleh tidak sinkron dengan profesi yang sedang dilakukan, disamping itu penelitian ini dilakukan di daerah Kabupaten. Kesamaan penelitian ini terletak pada letak usaha dari para pelaku UMKM yang berada di kota besar. Kesimpulan lainnya bahwa membuka usaha di kota besar atau di daerah tidak dipengaruhi oleh tingkat pendidikan karena disebabkan persaingan usaha yang besar serta kecilnya modal usaha yang membuat pelaku UMKM sulit untuk berkembang. Meskipun demikian, pendidikan tetap menjadi bagian penting hal ini dilihat dari pengujian hipotesis secara simultan bahwa pendidikan ikut serta mempengaruhi ketahanan ekonomi masyarakat.

\section{Pengaruh Pelatihan Terhadap Ketahanan Ekonomi Masyarakat}

Penelitian ini menunjukkan bahwa pelatihan berpengaruh terhadap ketahanan ekonomi masyarakat. Dalam mengembangkan usaha kecil, mikro dan menengah seorang pedagang tentu membutuhkan pelatihan, meskipun pelatihan yang diperoleh pemilik usaha belajar secara otodidak atau memperoleh pelatihan dan informasi-informasi informal lainnya. Menurut Susilo et.al (2014), pelatihan merupakan proses pendidikan jangka pendek yang menggunakan prosedur sistematis dan terorganisir sehingga tenaga kerja non manajerial mempelajari pengetahuan dan ketrampilan teknis untuk tujuan tertentu. Bahkan hasil penelitian Irawati (2018) menunjukkan bahwa pedagang atau pelaku UMKM harus memperoleh pembinaan atau pendampingan dalam rangka mempertahankan usahanya dari arus globalisasi dan persaingan semakin kompetitif. Pembinaan juga memiliki arti penting dalam mengembangkan usaha kecil. Pembinaan merupakan proses atau pengembangan yang mencakup urutan-urutan pengertian, diawali dengan mendirikan, menumbuhkan, memelihara pertumbuhan tersebut yang disertai usaha-usaha perbaikan, menyempurnakan dan mengembangkannya (Rasyid et al, 2002 dalam Alhempi, Raden, 2013). Sasaran dari pembinaan usaha kecil menengah adalah untuk mengembangkan usahanya menjadi lebih besar.

\section{Pengaruh Modal Terhadap Ketahanan Ekonomi Masyarakat}

Penelitian ini menunjukkan bahwa modal tidak serta merta berpengaruh terhadap ketahanan ekonomi masyarakat. Meskipun hasil penelitian ini bertolak belakang dengan Utari dan Dewi (2014) yang menyatakan bahwa modal secara parsial berpengaruh positif dan signifikan terhadap pendapatan UMKM di Kawasan Imam Bonjol Denpasar Barat. Menurut Ryanto (2001), yang menyatakan semakin besar modal perusahaan maka akan berpengaruh positif terhadap pendapatan yang diterima. Modal adalah faktor yang mempunyai peran cukup penting dalam proses produksi, karena modal diperlukan ketika pengusaha hendak mendirikan perusahaan baru atau untuk memperluas usaha yang sudah ada, tanpa modal yang cukup maka akan berpengaruh 
terhadap kelancaran usaha, sehingga akan mempengaruhi pendapatan yang diperoleh. Sesuai dengan karakteristik skala usahanya, UMKM tidak memerlukan modal dalam jumlah yang terlalu besar. Modal adalah barang-barang atau peralatan yang dapat digunakan untuk melakukan proses produksi. Menurut Riyanto (2001), modal tidak selalu identik dengan uang, namun dapat dikatakan sebagai segala sesuatu yang dapat dipakai untuk menghasilkan barang atau jasa. Meskipun demikian, modal menjadi salah unsur penting dalam memulai usaha bahkan termasuk faktor utama produksi, sebagaimana dari pengujian hipotesis secara simultan bahwa modal ikut serta mempengaruhi ketahanan ekonomi masyarakat.

\section{Pengaruh Teknologi Terhadap Ketahanan Ekonomi Masyarakat}

Penelitian ini menunjukkan bahwa teknologi menjadi variabel paling dominan berpengaruh terhadap ketahanan ekonomi masyarakat. Sebagaimana dengan penelitian Saleh dan Hadiyat (2016) bahwa hasil penelitian ini, secara umum dapat digambarkan bahwa penggunaan TI dikalangan pelaku UMKM di Kabupaten Belu relatif sudah memasyarakat, baik dalam hal kemampuan para pelaku usaha mengoperasikan komputer maupun dalam hal mengakses internet. Namun jika dilihat dari pemanfaatan komputer dan internet untuk mendukung pengelolaan atau manajemen UMKM mereka pada umumnya relatif masih rendah. Kemiripan hasil penelitian ini adalah penggunaan akses informasi dari pelaku usaha di Kabupaten Labuhanbatu mulai dari awal pendirian usaha informasi melalui telepon selular. Maksudnya teknologi pertama kali yang mendukung perkembangan usaha jenis informasinya berupa pengiriman barang, ketersediaan barang dan keterlambatan barang serta hal-hal lainnya yang dibutuhkan pedagang. Seiring dengan perkembangan teknologi yang pesat menuntut para pelaku usaha harus siap dan terbuka dengan perkembangan teknologi berupa internet. Melalui akses internet tersebut memberikan banyak informasi kepada pelaku usaha berkaitan dengan ekonomi serta dalam mengambil keputusan. Walaupun penggunaan teknologi bagi pelaku usaha dalam skala kecil, namun teknologi bukanlah besarnya atau kecilnya ukuran media yang digunakan, melainkan informasi-informasi yang berkaitan dengan usaha dan kegiatan mereka. Disamping itu, peranan teknologi bagi pelaku usaha mikro dan menengah dapat memasarkan dagangannya kepada siapapun termasuk keluarga, saudara dan jiran tetangga tanpa batas dan ruang.

\section{KESIMPULAN}

Berdasarkan hasil penelitian maka dapat ditarik beberapa kesimpulan untuk menjawab rumusan masalah yakni pendidikan tidak berpengaruh terhadap ketahanan ekonomi masyarakat. Membuka usaha di kota besar atau di daerah tidak dipengaruhi oleh tingkat pendidikan karena disebabkan persaingan usaha yang besar serta kecilnya modal usaha yang membuat pelaku UMKM sulit untuk berkembang. Meskipun demikian, pendidikan tetap menjadi bagian penting hal ini dilihat dari pengujian hipotesis secara simultan bahwa pendidikan ikut serta mempengaruhi ketahanan ekonomi masyarakat. Pelatihan berpengaruh terhadap ketahanan ekonomi masyarakat. Dalam mengembangkan usaha kecil, mikro dan menengah seorang pedagang tetap membutuhkan pelatihan, meskipun pelatihan yang diperoleh pemilik usaha belajar secara otodidak atau memperoleh pelatihan dan informasi-informasi informal lainnya. Modal tidak serta merta berpengaruh terhadap ketahanan ekonomi masyarakat, modal tidak selalu identik dengan uang, namun dapat dikatakan sebagai segala sesuatu yang dapat dipakai untuk menghasilkan barang atau jasa. Meskipun demikian, modal menjadi salah unsur penting dalam memulai usaha bahkan termasuk faktor utama produksi, sebagaimana dari pengujian hipotesis secara simultan bahwa modal ikut serta mempengaruhi ketahanan ekonomi masyarakat. Terakhir, teknologi menjadi variabel paling dominan berpengaruh terhadap ketahanan ekonomi masyarakat. Penggunaan 
teknologi bagi pelaku usaha dalam skala kecil, namun teknologi bukanlah besarnya atau kecilnya ukuran media yang digunakan, melainkan informasi-informasi yang berkaitan dengan usaha dan kegiatan mereka. Disamping itu, peranan teknologi bagi pelaku usaha mikro dan menengah dapat memasarkan dagangannya kepada siapapun termasuk keluarga, saudara dan jiran tetangga tanpa batas dan ruang.

\section{DAFTAR PUSTAKA}

Badan Pusat Statistik Daerah Kabupaten Labuhanbatu Selatan, 2019.

Irawati, Rina. 2018. Pengaruh Pelatihan Dan Pembinaan Terhadap Pengembangan Usaha Kecil. Jurnal JIBEKA Volume 12 No 1, 2018: 74-82

Jonker, Jan, Pennink. Bartjan J.W, Wahyuni. Sari. 2011. Metodologi Penelitian : Panduan Untuk dibidang Managemen. Salemba Empat, Jakarta

Nainggolan, Romauli. 2016. Gender, Tingkat Pendidikan Dan Lama Usaha Sebagai Determinan Penghasilan UMKM Kota Surabaya. Kinerja, Volume 20, No.1, Th. 2016: Hal. 1-12.

Nasution, Ade Parlaungan. "Studi Potensi Dan Peluang Ekonomi Kerakyatan Kota Batam." Jurnal Dimensi 2, no. 1 (2016).

Susilo et al. 2014. Pengaruh Pelatihan Terhadap Pengembangan Usaha Dikoperasi Unit Desa (KUD) "Marem" Desa Serut Kecamatan Panti Kabupaten Jembertahun 2013. Artikel Ilmiah Mahasiswa 2014.

Primiana, Ina. 2009. Menggerakkan Sektor Riil UKM \& Industri. Bandung: Alfabeta. Riyanto, Bambang. 2001. Dasar-dasar Perusahaan. Yogyakarta: Yayasan Penerbit.

Saleh, Baso dan Hadiyat, Yayat D. 2016. Penggunaan Teknologi Informasi di Kalangan Pelaku Usaha Mikro Kecil Menengah di Daerah Perbatasan (Studi di Kabupaten Belu Provinsi Nusa Tenggara Timur). Jurnal Pekommas, Vol. 1 No. 2, Oktober 2016: 141 - 152 .

Tarigan, R., 2004. Perencanaan Pembangunan Wilayah. Jakarta, P.T. Bumi Aksara.

Utari, Tri dan Dewi, Putu Martini. 2014. Pengaruh Modal, Tingkat Pendidikan Dan Teknologi Terhadap Pendapatan Usaha Mikro Kecil Dan Menengah (UMKM) Di Kawasan Imam Bonjol Denpasar Barat. E-Jurnal Ekonomi Pembangunan Universitas Udayana Vol. 3, No. 12, Desember 2014.

UU No 20 Tahun 2008 tentang Usaha Mikro, Kecil, dan Menengah (UMKM) 